\title{
Severe acute respiratory infections (SARI) from influenza in adult patients in Chile: the experience of a sentinel hospital
}

\author{
Alberto Fica, ${ }^{1}$ Viviana Sotomayor, ${ }^{2}$ Rodrigo Fasce, ${ }^{3}$ Jeannette Dabanch, ${ }^{1}$ \\ Andrés Soto, ${ }^{1}$ Paulo Charpentier, ${ }^{1}$ Gonzalo Guerrero, ${ }^{1}$ Felipe Olivares, ${ }^{1}$ \\ Vjera Triantafilo, ${ }^{4}$ Nathalie El Omeiri, ${ }^{5}$ and Marina Gaínza-Lein ${ }^{6}$
}

Suggested citation

Fica A, Sotomayor V, Fasce R, Dabanch J, Soto A, Charpentier P, et al. Severe acute respiratory infections (SARI) from influenza viruses in adult patients in Chile: the experience of a sentinel hospital. Rev Panam Salud Publica. 2019;43:e1. https://doi.org/10.26633/RPSP.2019.1

ABSTRACT Objective. To 1) describe clinical characteristics of adult patients in Chile with severe acute respiratory infections (SARI) associated with influenza viruses, and 2) analyze virus subtypes identified in specimens collected from those patients, hospital resources used in clinical management, clinical evolution, and risk factors associated with a fatal outcome, using observational data from the SARI surveillance network (SARInet).

Methods. Adults hospitalized from 1 July 2011 to 31 December 2015 with influenzaassociated SARI at a SARI sentinel surveillance hospital in Santiago were identified and the presence of influenza in all cases confirmed by reverse transcription polymerase chain reaction (RT-PCR), using respiratory samples.

Results. A total of 221 patients (mean age: 74.1 years) were hospitalized with influenzaassociated SARI during the study period. Of this study cohort, 91.4\% had risk factors for complications and $34.3 \%$ had been vaccinated during the most recent campaign. Pneumonia was the most frequent clinical manifestation, occurring in 57.0\% of the cohort; other manifestations included influenza-like illness, exacerbated chronic bronchitis, decompensated heart failure, and asthmatic crisis. Cases occurred year-round, with an epidemic peak during autumn-winter. Both influenza A (H1N1pdm09 and H3N2) and B virus co-circulated. Critical care beds were required for $26.7 \%$ of the cohort, and $19.5 \%$ needed ventilatory assistance. Multivariate analysis identified four significant factors associated with in-hospital mortality: 1) being bedridden (adjusted odds ratio (aOR): 22.3; 95\% confidence interval (CI): 3.0-164);2) admission to critical care unit (aOR: 8.9; CI: 1.44-55); 3) Pa0 /Fi0 ratio < 250 (aOR: 5.8; CI: 1.02-33); and 4) increased serum creatinine concentration (>1 mg/dL) (aOR: 5.47; CI: 1.20-24). Seasonal influenza vaccine was identified as a significant protective factor (aOR: 0.14; CI: 0.021-0.90).

Conclusions. Influenza-associated SARI affected mainly elderly patients with underlying conditions. Most patients evolved to respiratory failure and more than one-quarter required critical care beds. Clinical presentation was variable. Death was associated with host characteristics and disease-associated conditions, and vaccine was protective. Virus type did not influence outcome.

Keywords Influenza, human; respiratory tract infections; adult; hospitalization; risk factors; fatal outcome; Chile.

\footnotetext{
Infectious Disease Service, Hospital Militar de Santiago, Santiago, Chile. Send correspondence to: Alberto Fica, albertoficacubillos@gmail.com

2 Department of Epidemiology, Ministerio de Salud, Santiago, Chile.
}

\footnotetext{
Viral Hepatitis and Emerging Diseases Section, Viral Diseases Subdepartment, Instituto de Salud Pública de Chile, Santiago, Chile.

4 Central Laboratory, Hospital Militar de Santiago, Santiago, Chile.
}

\footnotetext{
Comprehensive Family Immunization Unit, Pan American Health Organization, Washington, D.C., United States of America.

6 School of Medicine, Universidad Austral de Chile-Campus Isla Teja, Valdivia, Chile.
} 
Influenza has a high burden of disease and mortality worldwide, especially among groups at increased risk for complications, such as children under 5 years old, the elderly, pregnant women, and individuals with chronic medical conditions (1-6). Influenza prevention requires periodic vaccination campaigns designed according to the virological information gathered at different sentinel points. Knowledge gained from pandemics in the past led to the development of the World Health Organization (WHO) Global Pandemics Preparedness Plan at the beginning of the $21^{\text {st }}$ century (7). This plan was designed to help countries prepare for influenza virus pandemics like the ones experienced in 2009, when timely detection of the emergent virus failed, impeding the effectiveness of mitigation measures $(8,9)$. One result of this experience was the development of an active surveillance network to monitor admitted patients with severe acute respiratory infections (SARI) in sentinel hospitals that includes appropriate sampling, laboratory testing, and early online reporting. The SARI surveillance network (SARInet) has been operating in various countries in Latin America and the Caribbean since 2011; in Chile, it includes six hospitals in different geographic regions (north, central, and south). Ongoing efforts to strengthen surveillance are focused on 1) detection of new emerging respiratory viruses; 2) analysis of the circulation of different influenza types and subtypes; 3) facilitation of vaccine composition; and 4) evaluation of vaccine and antiviral therapy effectiveness to help prevent death or complications (10). Using the observational data collected through SARInet, this study aimed to 1) describe clinical characteristics of adult patients in Chile with influenza-associated SARI, and 2) analyze virus subtypes identified in specimens collected from those patients, hospital resources used in clinical management, clinical evolution, and risk factors associated with a fatal outcome.

\section{MATERIALS AND METHODS}

\section{Study design}

This descriptive observational study used data from the SARI surveillance network complemented by information obtained from reviews of individual medical records. The researchers identified adult patients hospitalized with influenza-associated SARI between 1 July 2011 and 31 December 2015 at Hospital Militar, a SARI sentinel surveillance hospital in the metropolitan area of Santiago, Chile.

\section{Inclusion/exclusion criteria, case definition, and laboratory testing}

SARI cases were identified using the following standard case definition: measured/reported fever plus respiratory symptoms associated with tachypnea ( $\geq 30$ breaths/minute) and/or low pulse oximetry (blood oxygen saturation $<90 \%$ while breathing ambient air). However, fever was a conditional inclusion criterion, left to the discretion of the physician in charge of case recruitment, due to the older age of the study cohort, as described in more detail below.

Nasopharyngeal swab specimens collected from patients that met the SARI criteria were analyzed first by direct immunofluorescence (IF) for eight different viruses: influenza A and B, parainfluenza 1-3, respiratory syncytial virus, metapneumovirus, and adenovirus. Samples positive for influenza or negative for all respiratory viruses were processed further at the national reference laboratory (Instituto de Salud Pública de Chile), using reverse transcription polymerase chain reaction (RT-PCR) to detect influenza A or B and perform viral subtyping. All adult patients with SARI and influenza, based on molecular detection methods, were included in the study. Cases with incomplete information or readmissions were excluded.

\section{Clinical characterization, management, and outcome}

For each case, demographic and other information, including data on smoking; influenza vaccination (based on selfreport or relative's information); epidemiological week of admission; domiciliary oxygen use; residence in long-term care facilities; comorbidities; symptoms and signs at admission (e.g., cough, sputum, obstructive symptoms, rhinorrhea, headache, myalgia); systolic ( $<90 \mathrm{mmHg}$ ) or diastolic (<60 mmHg) hypotension; initial laboratory evaluation (hemoglobin concentration; leukocyte, lymphocyte, and platelet count; erythrocyte sedimentation rate (ESR); plasmatic lactic dehydrogenase (LDH); albumin; blood urea nitrogen (BUN); serum creatinine concentration; and C-reactive protein (CRP) concentration); and presence or absence of pneumonia (as interpreted by the physician in charge or based on the radiologist report). Pneumonia was classified as lobar or interstitial. Blood cultures were requested based on the discretion of attending physicians. Clinical presentation was classified in the following mutually exclusive groups: influenza-like illness (ILI) (no pneumonia, decompensated heart failure, or asthma); asthma (signs of obstruction without pneumonia or cardiovascular collapse); chronic bronchitis exacerbation (positive history, increased cough, sputum or dyspnea, and no pneumonia); pneumonia (as detected by chest $\mathrm{x}$-ray); and cardiovascular decompensation (heart failure diagnosed by physical examination). Data on variables associated with disease management (need for invasive or noninvasive mechanical ventilation; corticosteroid use (systemic or inhaled); vasoactive drugs; antiviral (oseltamivir); and antibiotic compounds prescription) were also obtained. Site of hospitalization (critical care or general ward beds) was also recorded, along with the CURB-65 pneumonia severity score (11), and outcome at discharge (deceased or alive).

\section{Statistical analysis}

Risk or protective factors associated with death or critical care unit (CCU) admission were identified by odds ratio (OR) calculations. Continuous variables were transformed to categorical variables to facilitate OR estimations. Factors identified by univariate analysis $(P<0.10)$ were integrated in a multivariate analysis by binary logistic regression.

\section{Ethics approval}

This study was approved by the Hospital Militar Institutional Review Board and, as a retrospective analysis of the data, deemed exempt from the informed consent requirement. Patient anonymity was assured during the analysis.

\section{RESULTS}

From 1 July 2011 to 31 December 2015 (4.5 years), 1637 adult patients with SARI were admitted to Hospital Militar, and 1 $583(96.7 \%)$ were tested for influenza using IF. Of the 1583 cases tested, 110 
were positive for influenza (6.9\%) and 102 were positive for other viruses (6.4\%). Of the 110 cases positive for influenza based on IF, 108 were confirmed by RT-PCR. The RT-PCR testing, which included 1282 of the 1371 cases with initially negative results, using IF (93.5\%), detected 117 additional cases of influenza infection. The IF sampling was incomplete due to rejection of the nasopharyngeal swab or a premortem condition. The RT-PCR processing was incomplete due to failure to deliver respiratory samples to the reference lab. Of the 225 adult patients admitted to Hospital Militar for SARI that were also found to experience influenza-associated SARI events, two $(0.9 \%)$ were missing relevant data and were therefore excluded from the study, and two others were admitted twice, resulting in a final count of 221 patients.

\section{General features}

Characteristics of the study cohort included older age (mean age: 74.1 years); prevalence of smoking (previous or current); chronic diseases or conditions, especially pulmonary (38.9\%), cardiovascular $(28.1 \%)$, and neurological $(26.2 \%)$, and diabetes mellitus (24.4\%) (Table 1). No cases of influenza were detected among pregnant women. Of all the variables, only age and tobacco smoking showed statistically significant differences by gender. Female patients were older (mean age of 77.7 years versus 69.4 years in males; $P<0.001$ ), and male patients smoked more $(18.6 \%$ versus $8.3 \%$ in females; $P<0.05)$. Risk factors for complications associated with influenza infections, other than pregnancy (older age; chronic heart, lung, or liver conditions; cancer; immunosuppression; and obesity), were present in almost all patients $(91.4 \%)$. Bedridden patients $(17.6 \%)$ and residents of long-term care facilities $(5.4 \%)$ were also identified, suggesting a potentially frail elderly study population. Approximately one-third $(34.3 \%)$ of the study cohort reported receiving the seasonal influenza vaccine during the most recent vaccination campaign (23 of the 221 cases had no information for this variable) (Table 1 ).

\section{Clinical presentation}

Cough was the most common symptom in patients admitted for influenza-associated SARI (reported by $93.2 \%$ )

TABLE 1. General characteristics of a group of adult patients admitted for influenzaassociated severe acute respiratory infections (SARI) at Hospital Militar $(n=221)$, Santiago, Chile, 2011-2015

\begin{tabular}{lr}
\hline Characteristic & Result \\
\hline Average age in years (range) & $74.1(22-99)$ \\
Age $\geq 65$ years (\%) & $167(75.6)$ \\
Female (\%) & $124(56.1)$ \\
Former smoker (\%) & $61(27.6)$ \\
Current smoker (\%) & $28(12.7)$ \\
Consumed alcohol (\%) & $5(2.3)$ \\
Had a chronic disease or condition (\%) & \\
Chronic obstructive pulmonary disease (COPD) & $70(31.7)$ \\
Asthma & $18(8.1)$ \\
Any respiratory condition & $86(38.9)$ \\
Heart disease & $62(28.1)$ \\
Chronic neurological disease & $58(26.2)$ \\
Diabetes mellitus & $54(24.4)$ \\
Chronic kidney disease or dialysis & $15(6.8)$ \\
Cancer & $14(6.3)$ \\
Immune suppression from disease or drugs & $11(5.0)$ \\
Obesity & $7(3.2)$ \\
Liver disease & $5(2.3)$ \\
Bedridden (\%) & $39(17.6)$ \\
Long-term care resident (\%) & $12(5.4)$ \\
Home oxygen user (\%) & $18(8.1)$ \\
Pregnant (\%) & $0(0.0)$ \\
Had a risk conditiona (\%) & $201(91.4)$ \\
One risk factor & $42(19.0)$ \\
Two risk factors & $82(37.1)$ \\
Received seasonal influenza vaccine (\%) & $78(35.3)$ \\
Mean length of stay in days (range) & $68(34.3)^{b}$ \\
\hline Souce:Prepactors & $10.9(1-64)$ \\
\hline
\end{tabular}

Source: Prepared by the authors based on the study data.

a Older age, chronic disease condition(s), cancer, immune suppression, or obesity.

${ }^{b}$ Of patients with available information ( 23 cases had no information for this variable).

(Table 2). More than one-quarter of the study cohort $(25.8 \%)$ had no fever. Other hallmark symptoms of influenza, such as myalgia, and those corresponding to upper respiratory viral infections (e.g., rhinorrhea and odynophagia), were relatively infrequent in this patient group $(10.4 \%-22.6 \%)$. More than half $(56.1 \%)$ of the patients presented obstructive bronchial signs, and about one-quarter $(26.7 \%)$ had systolic or diastolic hypotension (Table 2). Bronchial obstructive signs were significantly associated with chronic obstructive pulmonary disease (COPD) or asthma (OR: 5.2; CI: $2.8-9.9 ; P<0.0001)$. About two-thirds of the patients were admitted at their first consultation (142 or $64.3 \%$ ), with $62(28.1 \%)$ admitted at the second consultation and the rest (17 or $7.7 \%$ ) admitted after three to five visits.

Many patients did not present with the full array of SARI inclusion criteria. Low pulse oximetry was the most common finding (65.2\%). Tachypnea was detected in $<30 \%$ of patients (Table 2 ). A high percentage of patients had partial respiratory failure $(71.9 \%)$ and 29 patients (13.1\%) had global respiratory failure (Table 2). The latter condition was significantly associated with chronic lung conditions (OR: 3.7; CI: 1.6-8.5; P = 0.02). A low $\mathrm{PaO}_{2} / \mathrm{FiO}_{2}$ ratio $(<250)$ was frequent but not predominant $(44.8 \%)$.

Laboratory evaluation showed a low frequency of leukocytosis (30.3\%), thrombocytopenia $(15.8 \%)$, hyponatremia $(12.7 \%)$, and hypoalbuminemia (18.6) (Table 2). Frequently presented conditions included lymphopenia (49.8\%), altered kidney function parameters $(50.7 \%)$, increased LDH plasmatic concentration (36.7\%), and high CRP values (> 10 times the upper-normal value) (43.9\%).

Only about half $(57.0 \%)$ of the patients had pneumonia as a clinical presentation, 
TABLE 2. Clinical characteristics of a group of adult patients admitted for influenzaassociated severe acute respiratory infections (SARI) at Hospital Militar $(n=221)$, Santiago, Chile, 2011-2015

\begin{tabular}{|c|c|}
\hline Clinical characteristic & No. of patients (\%) \\
\hline \multicolumn{2}{|l|}{ Symptom } \\
\hline Cough & $206(93.2)$ \\
\hline Fever & $164(74.2)$ \\
\hline Myalgia & $50(22.6)$ \\
\hline Rhinorrhea & $28(12.7)$ \\
\hline Odynophagia & $23(10.4)$ \\
\hline Bronchial obstructive signs & $124(56.1)$ \\
\hline Systolic $(<90 \mathrm{mmHg})$ or diastolic $(<60 \mathrm{mmHg})$ hypotension & $59(26.7)$ \\
\hline Tachypnea ( $\geq 30$ breaths/min) & $57(25.8)$ \\
\hline Tachycardia (> 100 heartbeats/min) & $113(51.1)$ \\
\hline Low pulse oximetry (blood oxygen saturation $<90 \%$, ambient air) & $144(65.2)$ \\
\hline Low $\mathrm{PaO}_{2} / \mathrm{FiO}_{2}$ ratio $(<250)$ & $99(44.8)$ \\
\hline Partial respiratory failure & $159(71.9)$ \\
\hline Global respiratory failure & $29(13.1)$ \\
\hline No arterial gases taken & $33(14.9)$ \\
\hline Leukocytosis (white blood cell count > $12000 \mu \mathrm{L}$ ) & $67(30.3)$ \\
\hline Lymphopenia (blood count $<1000 / \mu \mathrm{L}$ ) & $110(49.8)$ \\
\hline Low platelet count $(<150000 / \mu \mathrm{L})$ & $35(15.8)$ \\
\hline Hypoalbuminemia $(<3.5 \mathrm{~g} / \mathrm{L})$ & $41(18.6)$ \\
\hline Hyponatremia $(<135 \mathrm{mEq} / \mathrm{L})$ & $28(12.7)$ \\
\hline Increased plasmatic lactic dehydrogenase (> $250 \mathrm{UI} / \mathrm{L})$ & $81(36.7)$ \\
\hline Increased blood urea nitrogen (BUN) concentration (> 20 mg/L) & $112(50.7)$ \\
\hline Increased serum creatinine concentration (> $1 \mathrm{mg} / \mathrm{dL})$ & $83(37.6)$ \\
\hline Increased C-reactive protein (> 100 mg/L; > 10 times upper-normal value) & $97(43.9)$ \\
\hline \multicolumn{2}{|l|}{ Clinical presentation } \\
\hline Influenza-like illness & $25(11.3)$ \\
\hline Asthmatic crisis & $14(6.3)$ \\
\hline Decompensated heart failure & $15(6.8)$ \\
\hline Community-acquired pneumonia & $126(57)$ \\
\hline Exacerbated chronic bronchitis & $24(10.9)$ \\
\hline Other ${ }^{\mathrm{a}}$ & $17(7.7)$ \\
\hline \multicolumn{2}{|l|}{ CURB-65 severity score } \\
\hline 0 & $17(7.8)$ \\
\hline $0-2$ & $135(61.1)$ \\
\hline$\geq 3$ & $84(38.0)$ \\
\hline
\end{tabular}

Source: Prepared by the authors based on the study data.

${ }^{a}$ Decompensated lung fibrosis, pneumonia mixed with myocardial infarction.

with the rest presenting with ILI (11.3\%), decompensated heart failure $(6.8 \%)$, asthmatic crisis $(6.3 \%)$, exacerbated chronic bronchitis $(10.9 \%)$, and other conditions (e.g., decompensated lung fibrosis, pneumonia mixed with myocardial infarction) (Table 2). Of those with pneumonia, 77 (61.1\%) had a chest $x$-ray with a consolidated pattern, and 49 (38.9\%) had an x-ray with an interstitial pattern. Scores for the CURB-65 criteria spanned the full range of possible results (0 to 5); $7.8 \%$ of patients had zero points. Blood cultures were requested for 171 patients $(77.4 \%)$ and six $(3.5 \%)$ cases were positive (two for Streptococcus pneumoniae, two for Staphylococcus aureus, one for Haemophilus influenzae, and one mixed infection-Escherichia coli and Pseudomonas aeruginosa-in a patient with acute leukemia, pancytopenia and pneumonia). Gender analysis did not show any differences other than more male patients with increased serum creatinine concentrations $(52.7 \%$ versus $29.2 \%$ in female patients; $P=0.001)$ and high CRP levels (> $100 \mathrm{mg} / \mathrm{dL})(53.8 \%$ versus $38.8 \%$ in female patients; $P=0.03$ ).

\section{Seasonal viral subtype distribution}

Influenza-associated SARI cases were distributed throughout the year, with an epidemic peak during autumn-winter (Figure 1). Cases were also detected in summer months (December to March in the Southern Hemisphere) (Figure 1). During the study period, influenza A cases predominated over influenza B events, with 173 (78.3\%) versus $48(21.7 \%)$ respectively. Except for one case, all influenza A cases were subtyped. For the whole group, influenza A belonging to H3N2 subtype predominated (123 cases or 55.7\%), with nearly equal distributions for influenza A(H1N1pdm09) (49 cases or $22.2 \%$ ) and influenza B events (48 cases or $21.7 \%$ ). Annual incidence analysis showed cocirculation of the three viral types/ subtypes, except for year 2012, when influenza $\mathrm{A}(\mathrm{H} 1 \mathrm{~N} 1 \mathrm{pdm} 09)$ events were not detected (Figure 2).

\section{Management and outcome}

The majority of the study cohort survived (195 cases or $88.2 \%), 25$ patients died $(11.3 \%)$, and one patient $(0.5 \%)$ was transferred without follow-up information. ${ }^{7}$ Mean length of stay (LOS) was 10.9 days (range: 1-64 days). LOS surpassed one week in 112 cases $(50.7 \%)$ and two weeks in 41 cases $(18.6 \%)$.

Most patients ( 162 or $73.3 \%$ ) were managed in general wards, with the remainder-59 or $26.7 \%$ - sent to the CCU (intensive or intermediate care beds). Invasive mechanical ventilation was required by 20 patients $(9.0 \%)$ and another 23 required noninvasive mechanical ventilation (10.4\%). Thus, $19.5 \%$ needed some form of ventilatory assistance. Vasoactive drugs were applied to 21 patients $(9.5 \%)$. Most patients received topical bronchodilators by nebulizers (207 cases or $93.7 \%$ ), and systemic corticosteroids were frequently applied (141 cases or $63.8 \%$ ). Simultaneous antiviral and antibiotic therapy were prescribed almost universally (193 cases or $87.3 \%$ ). Exclusive antiviral use (15 cases or $6.8 \%$ ) or antibiotic therapy (10 cases or $4.5 \%$ ) was uncommon. Only one patient $(0.5 \%)$ did not receive antimicrobial treatment; two other cases $(0.9 \%)$ had no information for the variable. Only two patients $(0.9 \%)$ required renal replacement therapy.

\footnotetext{
As the univariate analysis was limited to patients with a known mortality outcome, this loss to follow-up reduced the patient count for the model to 220 (versus 221 for the total study cohort).
} 
FIGURE 1. Distribution of influenza-associated severe acute respiratory infections (SARI) cases by month of symptom onset in a group of adult patients admitted at Hospital Militar $(n=221$ ), Santiago, Chile, 2011-2015

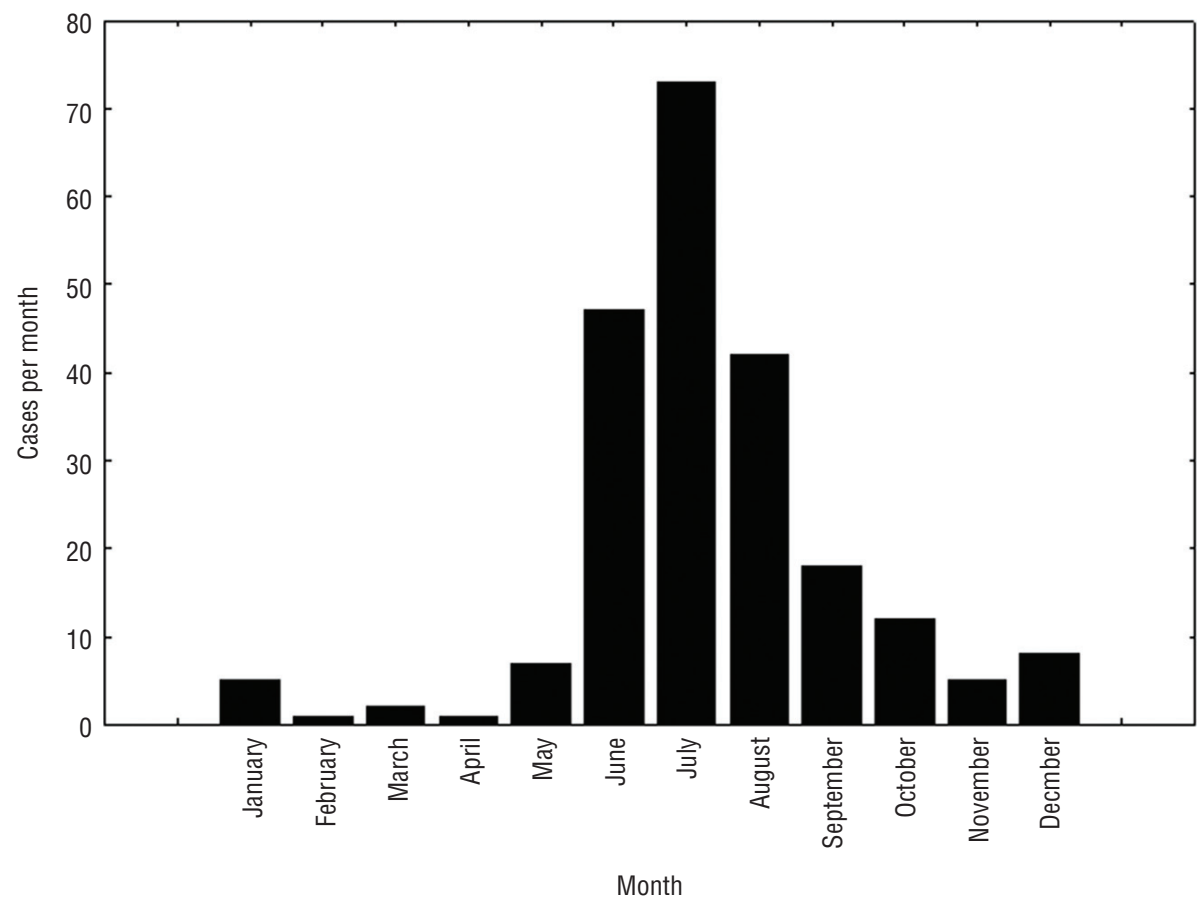

Source: Prepared by the authors based on the study data

FIGURE 2. Annual distribution of influenza-associated severe acute respiratory infections (SARI) cases by viral type/subtype in a group of adult patients admitted at Hospital Militar $(n=221)$, Santiago, Chile, 2011-2015

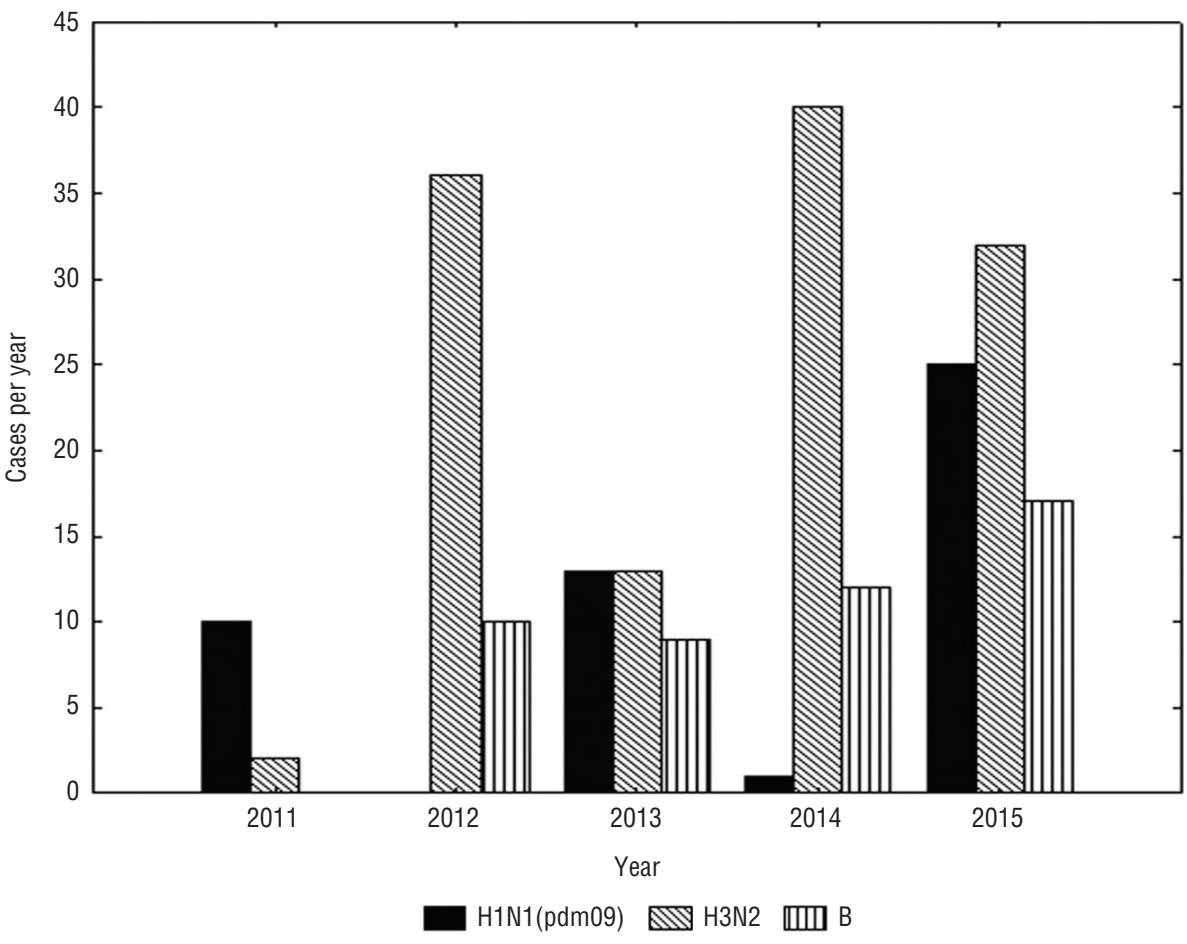

Source: Prepared by the authors based on the study data

\section{Risk factors for a fatal outcome}

In the univariate analysis, several factors were associated with in-hospital mortality, including preadmission conditions (being bedridden), disease-associated conditions (respiratory failure, renal failure, higher CURB-65 severity score, admission to CCU, use of vasoactive drugs, ventilatory assistance, increased LDH plasmatic levels, low platelet count, hypoalbuminemia, and lobar pneumonia) (Table 3). Patients that were vaccinated during the most recent vaccination campaign and those that initiated oseltamivir during the first three days following symptom onset were less likely to have a fatal outcome. Age, Comorbid conditions, viral type or subtype, and high CURB-65 severity score were not linked to a fatal outcome. A multivariate analysis was performed using binary logistic regression, incorporating the significant factors identified from the univariate analysis and relevant variables for appropriate adjusting (gender, age, presence of any risk factor, and infection with influenza $\mathrm{A}(\mathrm{H} 1 \mathrm{~N}-$ 1pdm09)). Redundant variables for severity (low albumin concentration, increased LDH levels, ventilatory assistance, and use of vasoactive drugs) were excluded. Bacteremia was also excluded from the model, due to the low number of cases. Multivariate analysis identified four factors statistically associated with a fatal outcome: being bedridden (aOR: 22.3); admission to CCU (aOR: 8.9); $\mathrm{PaO}_{2} / \mathrm{FiO}_{2}$ ratio < 250 (aOR: $5.8)$; and increased creatinine concentration (> $1 \mathrm{mg} / \mathrm{dL}$ ) (aOR: 5.47) (Table 3). Seasonal influenza vaccine was identified as a protective factor (aOR: 0.14).

\section{Comparison of vaccine composition with viral circulation}

Type and subtype distribution allowed for comparison of the vaccine composition with circulating influenza viruses. Information about vaccine composition was provided by the national reference laboratory. Annual comparison analysis was performed from April through March of the following year. Of the 68 patients in the study cohort that had received the seasonal vaccine, a total of $40(58.8 \%)$ had an influenza virus type/subtype with a composition similar to the vaccine. The remaining patients who received the seasonal 
TABLE 3. Analysis of factors affecting mortality in a group of adult patients admitted for influenza-associated severe acute respiratory infections (SARI) at Hospital Militar, Santiago, Chile, 2011-2015

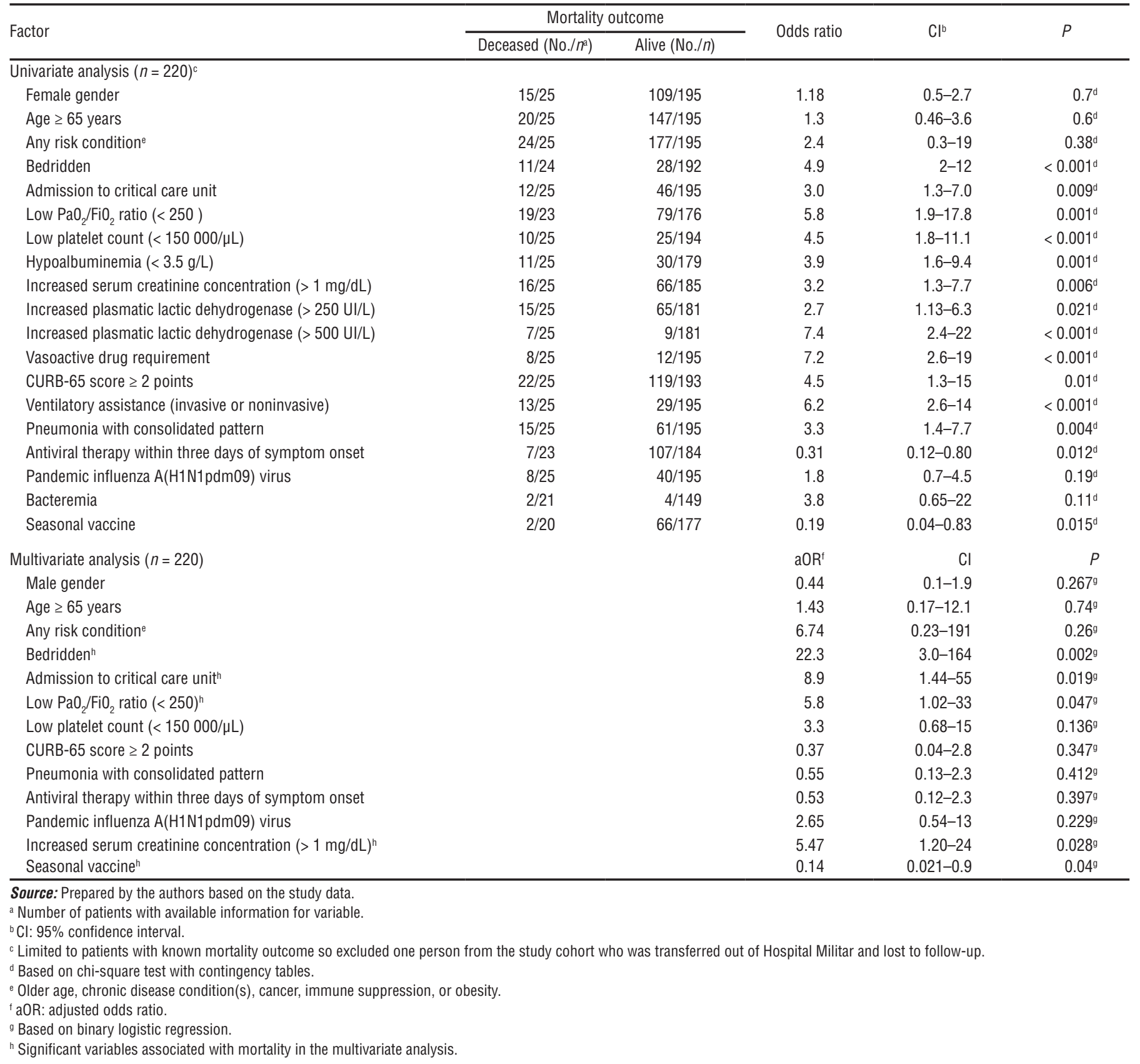

influenza inoculation ( 28 cases or $41.2 \%$ ) had a virus type/subtype with a composition that was different from the vaccine. As only two vaccinated patients died (one with a circulating influenza type/ subtype matching the composition of the vaccine, and one with a circulating type/ subtype that differed from it), further analysis to compare the impact of vaccine composition on mortality could not be performed. A detailed antigenic/vaccine matching analysis was not performed.

\section{DISCUSSION}

Sentinel surveillance of SARI at Hospital Militar demonstrated that despite a seasonal distribution, influenza was a near-permanent cause of hospital admissions year-round, in Chile's temperate climate. This pattern reinforces the need for suspicion, diagnosis, and appropriate treatment of this viral infection beyond assumed timeframes (autumn-winter). In this study, SARI affected mainly elderly, frail patients, and more than one-quarter of them required intensive or intermediate care beds. Moreover, in-hospital mortality was significant $(10 \%)$ and LOS prolonged. These findings underscore the extent of the influenza disease burden and the need for additional public health efforts to prevent it.

Three factors appeared to have magnified the consequences of influenza in the study cohort: 1) low coverage of the influenza vaccine, 2) host characteristics, 
and 3) disease-associated conditions. Low coverage of the influenza vaccine (only 34.3\%) decreased the preventive effect of seasonal vaccination-a strategy that has been shown to have a profound impact on vulnerable populations and reduce hospitalizations among elderly patients and those with diabetes mellitus, cancer, or dialysis. Seasonal vaccination also reduces mortality in the same groups $(2 ; 12-15)$. More than $90 \%$ of the patients in this patient group had indications for influenza seasonal vaccination, but influenza vaccine uptake was low, and after multivariate analysis the vaccine turned out to be a significant protective factor for in-hospital mortality. Influenza vaccines are offered free in Chile through the expanded program on immunization, and nationwide vaccination campaigns are carried out annually before the start of the influenza season. To the best of the authors' knowledge, these results are the first to demonstrate a protective effect from influenza vaccine uptake in SARI patients admitted to hospitals in Chile. It seems clear that, based on these study results, Chile should continue to increase influenza vaccine coverage. Host characteristics influenced severity and the need for CCU intensive or intermediate care beds and/or ventilatory assistance. This means that influenza affects hospitals by increasing not only the number of hospitalizations but also the demand for highly complex resources, amplifying its disease burden. Data on these factors have been previously reported (16), but the proportions of patients needing ventilatory support in this study were higher. Disease-associated conditions affecting the influenza outcome in this study included antiviral use, which was reported in almost all of the identified SARI patients (although timeliness of use was suboptimal in nearly half of them). As shown consistently in large observational studies, early initiation of antiviral therapy (within 3-4 days of first symptoms) had a protective effect on hospital mortality (16-18). This same effect was observed in this study, in the univariate analysis. However, the fraction of patients in this study without antiviral therapy was low $(<10 \%$, and only two of them died), limiting the ability to draw statistical conclusions.

The widely used tool for measuring pneumonia severity, the CURB-65 score (11), showed limitations in this study, with the SARI events that were analyzed scoring few points in a significant proportion of the study cohort. This limitation can be attributed to three factors: 1 ) the exclusion of pulse oximetry (an important tool for identifying patients at risk) in the CURB-65 score; 2) the low percentage of patients with tachypnea $(\geq 30$ breaths/minute) in this study $(<30 \%)$; and 3) the relatively low frequency of hypotension in patients with viral respiratory illnesses (about 16\%-21\%) versus bacterial invasive diseases (31\%) (19-21). Based on this study, it appears that some SARI events are not appropriately identified by the classical CURB-65 score. Therefore, using this tool to develop clinical decision rules could lead to underestimation of the seriousness of influenza-related symptoms-and the need for hospitalization-by health providers. This could be an important factor to consider in Chile, where management of community-acquired pneumonia in elderly patients in Chile is based on the CURB-65 score and admission of those with lower scores $(\leq 1)$ is discouraged.

Another important finding in this study was that some SARI patients had no fever, which may have been related to the older age of the study cohort, as elderly people may not experience a rise in body temperature. This phenomenon has important implications for appropriate recognition of SARI-affected patients. The authors believe fever should not be a SARI criterion for surveillance purposes if other criteria are present to ensure appropriate recognition of every case and the disease burden associated with respiratory viruses.

In this study cohort, a wide array of clinical presentations was observed, including pneumonia, asthmatic crisis, ILI, chronic bronchitis exacerbation, decompensated heart failure, and other conditions, underscoring the broad spectrum in which influenza must be prevented, suspected, diagnosed, and treated (22-25). In addition, in this patient group, pneumonia presented with both consolidated and interstitial lung patterns, demonstrating once again that $\mathrm{x}$-ray findings are not associated with specific etiologies. For example, in a recent report, viral etiologies were associated with lung x-ray consolidation (59\% of cases) as well as infiltrates (42\%). On the other hand, bacterial-only events showed infiltrates in 31\% of patients (26).

Lymphopenia $(<1000 / \mu \mathrm{L})$ and increased CRP in plasma ( $>10$ times the upper-normal value) have been previously described in the literature, demonstrating the systemic involvement of influenza infection $(16,20)$. In this study, altered renal function was frequently detected, but non-stringent criteria ("above normal values") were used. In addition to dehydration, several mechanisms have been identified in patients suffering from acute renal failure during influenza infection, including rhabdomyolysis, hemolytic uremic syndrome, acute glomerulonephritis, disseminated intravascular coagulation, and acute interstitial nephritis (27). In this study, two patients with renal failure $(0.9 \%$ of the study cohort) presented with acute glomerulonephritis (reported elsewhere (27)) and required renal replacement therapy.

Several in-hospital mortality risk factors for severe influenza requiring hospital admission have been described. They include delayed medical attention; lung, kidney, liver, or cardiovascular disease; cancer chemotherapy; increased BUN or creatinine concentration; a high Simplified Acute Physiology Score (SAPS) or Sequential Organ Failure Assessment (SOFA) score; age $>65$ or $>80$ years; admission to the intensive care unit (ICU); development of acute respiratory distress syndrome (ARDS); bilateral lung involvement; mechanical ventilation requirement; superinfection; corticosteroid use; and pregnancy (28-34). The in-hospital risk factors found in this study cohort included admission to critical care beds; low $\mathrm{PaO}_{2} / \mathrm{FiO}_{2}$ ratio; and high creatinine concentration. Being bedridden was another identified risk factor and to some extent a proxy of older age and severe comorbidities; $28 \%$ of bedridden patients in the study cohort died. No association was found between influenza virus type and mortality, suggesting that viral type/ subtype does not play a role in the final outcome of influenza-associated SARI in the elderly, frail population in Chile.

\section{Limitations}

This study had several limitations. First, the study cohort was highly homogeneous for several variables, which impeded statistical comparisons. For example, most patients were elderly, so there were not enough younger people in this patient group to investigate if older age was linked to a higher mortality rate. The use of antivirals by most of the patients in this group created the 
same type of limitation. Second, the search for viral or bacterial coinfection was mainly restricted to blood cultures, which led to another study limitation. No systematic search for respiratory viral coinfection was attempted, except during year 2015, when this type of coinfection was detected in $12 \%$ of the study cohort (manuscript in preparation), and neither pneumococcal urinary antigen nor serological studies for atypical agents were routinely included during the whole study period. However, blood cultures were collected from $77.4 \%$ of patients and only a small fraction (3.5\%) were positive for bacterial species, including Staphylococcus aureus and Streptococcus pneumoniae and, in one case, bacteremic Haemophilus influenzae, all of which have been found to be associated with influenza infection in previous studies $(35,36)$. Viral-viral coinfection appears to be low in adults with asthma attacks or acute exacerbations of chronic bronchitis (24), so it seems unlikely that other, unexplored viral etiologies

Ciapponi A, Bardach A, Glujovsky $\mathrm{D}$, Aruj P, Mazzoni A, et al. Burden of influenza in Latin America and the Caribbean: a systematic review and meta-analysis. Influenza Other Respir Viruses. 2013;7(6): 1017-32.

2. Mertz D, Kim TH, Johnstone J, Lam PP, Science M, Kuster SP, et al. Populations at risk for severe or complicated influenza illness: systematic review and metaanalysis. BMJ. 2013; 347:f5061.

3. Miller M, Viboud C, Simonsen L, Olson DR, Russell C. Mortality and morbidity burden associated with A/H1N1pdm influenza virus: who is likely to be infected, experience clinical symptoms, or die from the H1N1pdm 2009 pandemic virus? PLoS Curr. 2009;1:RRN1013.

4. Ortiz JR, Neuzil KM, Shay DK, Rue TC, Neradilek MB, Zhou H, et al. The burden of influenza-associated critical illness hospitalizations. Crit Care Med. 2014;42(11): 2325-32.

5. Fischer WA 2nd, Gong M, Bhagwanjee S, Sevransky J. Global burden of influenza: contributions from resource limited and low-income settings. Glob Heart. 2014;9(3): 325-36.

6. Caini S, Huang QS, Ciblak MA, Kusznierz G, Owen R, Wangchuk S, et al. Epidemiological and virological characteristics of influenza B: results of the Global Influenza B Study. Influenza Other Respir Viruses. 2015;9 Suppl 1:3-12.

7. World Health Organization. WHO global influenza preparedness plan: the role of $\mathrm{WHO}$ and recommendations for national influenced severity or outcomes in the study cohort. On the other hand, bacterial-viral coinfection rates in adult patients with pneumonia ranged from $3 \%-17 \%$ in previous studies $(22,23,26)$, so the frequency of this type of coinfection could have been higher than estimated through blood cultures in this study. Unfortunately, the extreme age of the patients in the study cohort, which led to limited comprehension and cooperation, hampered the collection of adequate bronchial samples for investigation of bacterial causes by sputum cultures. Another limitation was that chest $\mathrm{x}$-rays were not systematically evaluated by different observers, a strategy that could have changed the frequency of pneumonia associated with influenza in this patient group.

\section{Conclusions}

These study results indicate that influenza is a relevant cause of admissions for SARI, especially among elderly frail

\section{REFERENCES}

measures before and during pandemics. Geneva: WHO; 2005. Available from: http:/ / www.who.int/csr/resources/publications/ influenza/WHO_CDS_CSR_GIP_2005_5. pdf Accessed 30 September 2017.

8. Falagas ME, Cholevas NV, Kapaskelis AM, Vouloumanou EK, Michalopoulos A, Rafailidis PI. Epidemiological aspects of 2009 H1N1 influenza: the accumulating experience from the Northern Hemisphere. Eur J Clin Microbiol Infect Dis. 2010;29(11): 1327-47.

9. Charu V, Chowell G, Palacio Mejia LS, Echavarría-Zuno S, Borja-Aburto $\mathrm{VH}$, Simonsen L, et al. Mortality burden of the A/H1N1 pandemics in Mexico: a comparison of deaths and years of life lost to seasonal influenza. Clin Infect Dis. 2011;53(10):985-93.

10. Ministerio de Salud (CL). Guia de vigilancia intensificada de las infecciones respiratorias agudas graves. Santiago: MINSAL; 2016. Available from: http://epi.minsal.cl/ wp-content/uploads / 2017/10/GuiaVigilancia-Intensificada-IRA-version2016. pdf Accessed 30 September 2017.

11. Lim WS, van der Eerden MM, Laing R, Boersma WG, Karalus N, Town GI, et al. Defining community acquired pneumonia severity on presentation to hospital: an international derivation and validation study. Thorax. 2003;58(5):377-82.

12. Beyer WE, McElhaney J, Smith DJ, Monto AS, Nguyen-Van-Tam JS, Osterhaus AD. Cochrane re-arranged: support for policies to vaccinate elderly people against influenza. Vaccine. 2013;31(50):6030-3. patients, and requires intensive care resources. Pneumonia is not the only form of clinical presentation, and influenza-related admissions, associated with every viral type and subtype, occur year-round. In this study, 1 out of 10 admitted patients had a fatal outcome related to host characteristics (being bedridden) and disease-associated conditions/variables (admission to CCU, low $\mathrm{PaO}_{2} / \mathrm{FiO}_{2}$ ratio, and increased serum creatinine concentration). The widely used CURB-65 severity score did not predict an adverse outcome or the virus type or subtype. A seasonal vaccine was protective, so efforts should be intensified to increase population coverage.

\section{Conflicts of interest. None.}

Disclaimer. Authors hold sole responsibility for the views expressed in the manuscript, which may not necessarily reflect the opinion or policy of the RPSP / PAJPH or the Pan American Health Organization (PAHO).
13. Remschmidt C, Wichmann O, Harder T. Vaccines for the prevention of seasonal influenza in patients with diabetes: systematic review and meta-analysis. BMC Med. 2015;13:53.

14. Remschmidt C, Wichmann O, Harder T. Influenza vaccination in patients with end-stage renal disease: systematic review and assessment of quality of evidence related to vaccine efficacy, effectiveness, and safety. BMC Med. 2014;12:244.

15. Eliakim-Raz N, Vinograd I, Zalmanovici Trestioreanu A, Leibovici L, Paul M. Influenza vaccines in immunosuppressed adults with cancer. Cochrane Database Syst Rev. 2013;(10):CD008983.

16. Lee N, Choi KW, Chan PK, Hui DS, Lui GC, Wong BC, et al. Outcomes of adults hospitalised with severe influenza. Thorax. 2010;65(6):510-5.

17. Hsu J, Santesso N, Mustafa R, Brozek J, Chen YL, Hopkins JP, et al. Antivirals for treatment of influenza: a systematic review and meta-analysis of observational studies. Ann Intern Med. 2012;156(7): 512-24.

18. McGeer A, Green KA, Plevneshi A, Shigayeva A, Siddiqi N, Raboud J, et al. Antiviral therapy and outcomes of influenza requiring hospitalization in Ontario, Canada. Clin Infect Dis. 2007;45(12): 1568-75.

19. Fica A, Dabanch J, Andrade W, Bustos $P$, Carvajal I, Ceroni C, et al. Clinical relevance of rhinovirus infections among adult hospitalized patients. Braz J Infect Dis. 2015;19(2):118-24. 
20. Armstrong M, Fica A, Dabanch J, Olivares F, Fasce R, Triantafilo V. Morbilidad y mortalidad asociada a hospitalizaciones por influenza pandémica A (H1N1) 2009 en dos hospitales de la Región Metropolitana y evaluación de su impacto económico. Rev Chilena Infectol. 2012;29(6):664-71.

21. Fica A, Bunster N, Aliaga F, Olivares F, Porte L, Braun S, Dabanch J, Hormazabal JC, Hernández A, Benavides MG. Bacteremic pneumococcal pneumonia: serotype distribution, antimicrobial susceptibility, severity scores, risk factors, and mortality in a single center in Chile. Braz J Infect Dis. 2013;18(2):115-23.

22. Jennings LC, Anderson TP, Beynon KA, Chua A, Laing RT, Werno AM, et al. Incidence and characteristics of viral community-acquired pneumonia in adults. Thorax. 2008;63(1):42-8.

23. Johnstone J, Majumdar SR, Fox JD, Marrie TJ. Viral infection in adults hospitalized with community-acquired pneumonia: prevalence, pathogens, and presentation. Chest 2008;134(6):1141-8.

24. Biancardi E, Fennell M, Rawlinson W, Thomas PS. Viruses are frequently present as the infecting agent in acute exacerbations of chronic obstructive pulmonary disease in patients presenting to hospital. Intern Med J. 2016;46(10):1160-5.

25. Jacoby DB. Virus-induced asthma attacks. JAMA. 2002;287(6):755-61.

26. Jain S, Self WH, Wunderink RG, Fakhran S, Balk R, Bramley AM, et al. Community-acquired pneumonia requiring hospitalization among U.S. adults. N Engl J Med. 2015;373(5):415-27.

27. Aceituno D, Fica A, Fasce R, Andrade W, Díaz C. Glomerulonefritis aguda con requerimiento de diálisis asociada a influenza AH1N1pdm09: comunicación de dos casos. Rev Chilena Infectol. 2017;34(1):81-6.

28. Cvetanovska M, Milenkovik Z, Uroshevik VK, Demiri I, Cvetanovski V. Factors associated with lethal outcome in patients with severe form of influenza. Pril (Makedon Akad Nauk Umet Odd Med Nauki). 2016; 37(2-3):63-72.

29. Ramos JM, García-Navarro MM, González de la Aleja MP, Sánchez-Martínez R, Gimeno-Gascón A, Reus S, et al. Seasonal influenza in octogenarians and nonagenarians admitted to a general hospital: epidemiology, clinical presentation and prognostic factors. Rev Esp Quimioter. 2016;29(6):296-301.

30. Maheshwari M, Maheshwari S. Clinicoradiological profile and outcome of novel H1N1-infected patients during 2009 to 2014 pandemic at tertiary referral hospital in Rajasthan. J Assoc Physicians India. 2015;63(5):42-5.

31. Mata-Marín LA, Mata-Marín JA, VásquezMota VC, Arroyo-Anduiza CI, GaytánMartínez JE, Manjarrez-Téllez B, et al. Risk factors associated with mortality in patients infected with influenza A/H1N1 in Mexico. BMC Res Notes. 2015;8:432.

32. Shah NS, Greenberg JA, McNulty MC, Gregg KS, Riddell J, Mangino JE, et al. Severe influenza in 33 US hospitals,
2013-2014: complications and risk factors for death in 507 patients. Infect Control Hosp Epidemiol. 2015;36(11):1251-60.

33. Lee N, Leo YS, Cao B, Chan PK, Kyaw WM, Uyeki TM, et al. Neuraminidase inhibitors, superinfection and corticosteroids affect survival of influenza patients. Eur Respir J. 2015;45(6):1642-52.

34. Meerhoff TJ, Simaku A, Ulqinaku D, Torosyan L, Gribkova N, Shimanovich V, et al. Surveillance for severe acute respiratory infections (SARI) in hospitals in the WHO European region - an exploratory analysis of risk factors for a severe outcome in influenza-positive SARI cases. BMC Infect Dis. 2015;15:1.

35. Rice TW, Rubinson L, Uyeki TM, Vaughn LM, John BB, Miller RR 3rd, et al. Critical illness from 2009 pandemic influenza A (H1N1) virus and bacterial co-infection in the United States. Crit Care Med. 2012;40(5):1487-98.

36. Damasio GA, Pereira LA, Moreira SD Duarte dos Santos SN, Dalla-Costa LM, et al. Does virus-bacteria coinfection increase the clinical severity of acute respiratory infection? J Med Virol. 2015;87(9): 1456-61.

Manuscript submitted 24 October 2017. Revised version accepted for publication on 16 June 2018. 
RESUMEN

\section{La infección respiratoria aguda grave asociada a la gripe en pacientes adultos en Chile: experiencia de un hospital centinela}

Objetivos. 1) Describir las características clínicas de los pacientes adultos con infección respiratoria aguda grave relacionada con virus gripales en Chile, y 2) analizar los subtipos de los virus identificados en las muestras recogidas de estos pacientes, los recursos hospitalarios empleados en el tratamiento clínico, la evolución clínica y los factores de riesgo asociados a un desenlace mortal, mediante los datos de observación de la red de vigilancia de las infecciones respiratorias agudas graves (SARInet).

Métodos. Se identificaron los adultos hospitalizados entre el 1 de julio del 2011 y el 31 de diciembre del 2015 con infección respiratoria aguda grave relacionada con la gripe en un hospital de vigilancia centinela de esta afección en Santiago y se confirmó la presencia de gripe en todos los casos por medio de la reacción en cadena de la polimerasa con transcriptasa inversa realizada en muestras de las vías respiratorias

Resultados. Un total de 221 pacientes (con una media de edad de 74,1 años) fueron hospitalizados con infección respiratoria aguda grave relacionada con la gripe durante el período de estudio. En esta cohorte de estudio, 91,4 \% presentó factores de riesgo de complicaciones y 34,3 \% había recibido la vacuna en la campaña más reciente. La neumonía fue la manifestación clínica más frecuente y afectó a 57,0 \% de la cohorte; otras manifestaciones fueron el síndrome gripal, la bronquitis crónica exacerbada, la insuficiencia cardíaca descompensada y la crisis asmática. Los casos se presentaron durante todo el año y alcanzaron un pico epidémico durante el otoño y el invierno. Tanto el virus de la gripe de tipo A (H1N1pdm09 y H3N2) y tipo B circularon simultáneamente. En 26,7 \% de la cohorte se precisaron cuidados intensivos y en $19,5 \%$ fue necesario recurrir a la respiración asistida. El análisis multifactorial detectó cuatro factores fundamentales relacionados con la mortalidad hospitalaria: 1) la postración (razón de posibilidades ajustada [ORA]: 22,3; intervalo de confianza [IC] de $95 \%$ : 3,0-164); 2) la admisión en la unidad de cuidados intensivos (ORA: 8,9; IC: $1,44-55) ; 3$ ) un coeficiente $\mathrm{PaO}_{2} / \mathrm{FiO}_{2}$ inferior a 250 (ORA: 5,8; IC: 1,02-33), y 4) una mayor concentración de creatinina sérica (> $1 \mathrm{mg} / \mathrm{dL})$ (ORA: 5,47; IC: 1,20-24). Se determinó que la vacuna contra la gripe estacional era un factor protector significativo (ORA: 0,14; IC: 0,021-0,90).

Conclusiones. La infección respiratoria aguda grave asociada a la gripe afectó a pacientes predominantemente ancianos con afecciones subyacentes. La mayoría de los pacientes evolucionó en una insuficiencia respiratoria y más de una cuarta parte precisó cuidados intensivos. El cuadro clínico fue variable. La mortalidad estuvo relacionada con las características del huésped y los trastornos relacionados con la enfermedad, y la vacuna tuvo un efecto protector. El tipo vírico no influyó en los desenlaces.

Palabras clave Gripe humana; infecciones del sistema respiratorio; adulto; hospitalización; factores de riesgo; resultado fatal; Chile. 
RESUMO

\section{Infecção respiratória aguda grave (SARI) decorrente da influenza em pacientes adultos no Chile: experiência de um hospital-sentinela}

Palavras-chave
Objetivo. Descrever as características clínicas de pacientes adultos com infecção respiratória aguda grave (SARI) associada ao vírus da influenza e analisar os subtipos virais identificados em amostras coletadas destes pacientes, os recursos hospitalares empregados no tratamento clínico, a evolução clínica e os fatores de risco clínicos associados a um desfecho fatal, a partir de dados observacionais da rede de vigilância de SARI (SARInet) no Chile.

Métodos. Foram identificados os adultos hospitalizados com SARI associada a influenza em um hospital-sentinela de vigilância de SARI, em Santiago, de 1o de julho de 2011 a 31 de dezembro de 2015. A ocorrência de influenza foi confirmada em amostras respiratórias em todos os casos com a reação em cadeia da polimerase via transcriptase reversa (RT-RCP).

Resultados. Ao todo, 221 pacientes (idade média de 74,1 anos) foram hospitalizados com SARI associada a influenza no período de estudo. Nesta coorte, 91,4\% apresentavam fatores de risco para complicação e 34,3\% haviam sido vacinados na última campanha de vacinação. Pneumonia foi a manifestação clínica mais frequente, ocorrendo em $57,0 \%$ da coorte. Outras manifestações foram doença gripal, bronquite crônica exacerbada, insuficiência cardíaca descompensada e crise asmática. Os casos estiveram distribuídos ao longo do ano, com pico epidêmico no outono-inverno. Houve circulação simultânea dos vírus da influenza A (H1N1pdm09 e H3N2) e B. Leitos de terapia intensiva foram necessários em $26,7 \%$ da coorte e suporte ventilatório, em 19,5\%. Na análise multivariada, quatro fatores importantes associados à mortalidade hospitalar foram identificados: estar restrito ao leito (odds ratio ajustado [ORaj] 22.3; intervalo de confiança de 95\% [IC 95\%] 3.0-164); ser admitido na unidade de terapia intensiva (ORaj 8.9, IC 95\% 1.4 4-55); relação Pa02/Fi02 <250 (ORaj 5.8; IC 95\% 1.02-33) e aumento da creatinina sérica (>1 mg/dl) (ORaj 5.47; IC 95\% 1.20-24). A vacinação sazonal contra influenza foi identificada como importante fator de proteção (ORaj 0.14; IC 95\% 0.021-0.90).

Conclusões. ASARI associada a influenza acometeu sobretudo pacientes idosos com doenças preexistentes. A maioria dos pacientes evoluiu com insuficiência respiratória e mais de um quarto precisou de cuidados intensivos. O quadro clínico foi variável. Morte foi associada às características do hospedeiro e problemas relacionados à doença. A vacinação teve efeito protetor e o tipo viral não influiu no desfecho.

Influenza humana; infecções respiratórias; adulto; hospitalização; fatores de risco; evolução fatal; Chile. 